\title{
Agriculture Sustainability: A California Agribusiness Students' Perspective
}

\author{
Pei $\mathrm{Xu}^{1} \&$ David Vera ${ }^{2}$ \\ ${ }^{1}$ Agricultural Business Department, California State University, Fresno, USA \\ ${ }^{2}$ Economics Department, California State University, Fresno, USA \\ Correspondence: Pei Xu, Agricultural Business Department, California State University, Fresno, 5245 N Backer \\ Avenue, M/S PB101, Fresno, CA 93740-8001, USA. E-mail: pxu@csufresno.edu
}

$\begin{array}{ll}\text { Received: January 13, } 2014 & \text { Accepted: March 17, } 2014 \quad \text { Online Published: April 18, } 2014 \\ \text { doi:10.5539/ijbm.v9n5p1 } & \text { URL: http://dx.doi.org/10.5539/ijbm.v9n5p1 }\end{array}$

\begin{abstract}
Agribusiness managers as the major players in the agricultural industry greatly determine agribusiness practices and affectperception about agricultural sustainability. This study develops a framework to analyze how agribusiness students, the future agribusiness managers, in California view sustainable agriculture. An educational program was created and implemented to raise awareness and educate students about agricultural sustainability. Pre-and post-surveys were administered to collect relevant data and a conditional logit model was estimated. Our main results suggest that: 1) the educational program is more influential on the ratings of the external social and environmental sustainability than on economic and internal social sustainability; 2) participating in the educational program helped future managers realize the importance of obtaining stable income to achieve economic sustainability; and 3) water quality and farm continuity are important attributes infarm environmental and internal social sustainability. Given the lack of consensus on how to define agricultural sustainability, this study provides insightful information to help understand how future agriculture managers perceive sustainable farming.
\end{abstract}

Keywords: agriculture sustainability, agriculture sustainability in California, agribusiness students' perception on sustainability, sustainable agriculture

\section{Introduction}

Increasing awareness of farming related environmental pollution, anxiety about food safety and security, and concerns about the long-term sustainability of production resources, have resulted in recent years' heightened debate about agriculture sustainability (Hodge, 1993). Some argue that sustainable agriculture centers on organic farming and point to the expansion of organic farms at $12 \%$ per year due to an increasing consumer demand for safe foods (Scofield, 1986; York Jr., 1991; USDA, 2000). Others equate sustainable agriculture with low input agriculture (Edwards, 1987), low external input sustainable agriculture (Reijntjes, Bertus, \& Water-Bayer, 1992); and agro-ecology (Altieri, 1995), to emphasize the resource saving aspect of sustainable production. However, sustainable farming is also believed to deviate from the aforementioned practices because it is not codified as laws as other farming practices (MacCormack, 1995). Some have argued that sustainable farming involves different parties in a broader system than just production methods; this makes sustainable farming more difficult to define. For instance, agricultural chemical companies claim that conventional farming is more sustainable than organic farming because agricultural chemicals help better achieve farm economic sustainability (Whitby \& Adger, 1996). As a result, the ultimate goal of achieving consensus and understanding of what agricultural sustainability is among goal-conflicting parties often ends in vain (Francis, 1990). Despite the rising public concerns, there is indeed no agreed definition of agricultural sustainability.

Diverse views exist about sustainable farming. For example, it is very possible that a sustainable system being tested efficient for one farm at one point in time, may not be efficient for another farm at a different time (Ikerd, 1993; Rigby \& Caceres, 2001). Sustainable system is used to encompass not just conservation of non-renewable resources of soil, energy, and minerals; but it also encompasses issues of environmental, economic and social sustainability (Lampkin \& Measures, 1995; Van Calker, Berentsen, Giesen, \& Huirne, 2005; Sydorovych \& Wossink, 2008). Moreover, sustainable farming is found to be compatible with both small and large farms (Pretty, 1995; Rigby \& Caceres, 2001). Even though sustainability farming means different things to different 
people, two broad definitions are usually cited. Brandtland (1987) defined sustainability as "Humanity has the ability to make development sustainable to ensure that it meets the needs of the present without compromising the ability of future generations to meet their own needs. Barrow (1991) emphasized the environmental influence of sustainability and believed that sustainability is the development process to improve the quality of human life in the carrying capacity of supporting ecosystems such that: "Governments, development, aid agencies, and conservation organizations should support projects that combine rural development and the conservation and sustainable use of wild species and ecosystems" (p. 62). These two definitions reflect specific economic, social, or ecological concerns of different groups.

In the case of agricultural sustainability, future farm managers as the main players in the agricultural industry have expressed a unique view about sustainability. The view of these managers can greatly affect their future farming practices, and thus reshape the future value of sustainability in agriculture. The aim of this paper is to develop a framework to analyze how future agribusiness managers in California view sustainable agriculture. California is the largest food supplier in the United States; but opinions of its future agribusiness managers on sustainability issues have not been examined. We developed an educational program to raise awareness of sustainability among agriculture students. The program was available to agribusiness management students at a California State University campus. After implementing the program, we quantified its impact on students' perceptions towards sustainability. We administered two online surveys, one prior to the implementation of the educational program and one immediately after the completion of the program. Data from the questionnaire were used to estimate a conditional log it model and to identify factors affecting opinions on sustainability. This study aims to contribute to the literature by: 1) identifying key attributes affecting understandings of economic, internal social, external social and environmental sustainability; 2) measuring the impact of the educational program on sustainability perceptions; 3 ) analyzing the impact of family farm ownership on sustainability perceptions; and 4) quantifying the gender impact on sustainability perceptions.

\section{Literature Review}

According to Lewandowski, Ha"rdtlein, and Kaltschmitt (1999), agricultural sustainability is the management and utilization of agricultural system to achieve biological diversity, sufficient supply of food, renewal of production capacity, and improved ecological, economic and social agricultural activities at local, national and international level. Previously published studies have discussed the feasibility of forming a general understanding and consensus on agricultural sustainability (Gafsi, Legagneux, Nguyen, \& Robin, 2006; Van Cauwenbergh et al., 2007; Sydorovych \& Wossink, 2008). Environmentalists view agricultural sustainability as a multifunctional system to protect rural communities and to criticize the negative impact of agricultural practices on ecosystems and the global environment (Cairol, Coudel, \& Laplana, 2008). These environmental conscious communities were worried about agriculture's reduced ability to feed the world without scarifying additional natural resources (Paarberg, 2008). The affluent classes view sustainable agriculture as the likeness of local and organic products and the disinclination of genetically modified food (Siegrist, 2003). The debates among different groups suggest that a general agreement on what agricultural sustainability is has not been achieved.

Why does agricultural sustainability mean different things to different groups? The literature relates this to the political views of the stakeholders (Aerni, 2002). For example, Fairclough (2004) pointed out that small-scale farmers are found to be the guardians of sustainable agriculture who would protect the scarce public resources and curb economic globalization, i.e. the trade of food, for the protection of the already depleted natural resources. Aerni (2009) used a sample data on farmers' opinion from Switzerland and New Zealand to conclude that, compared to Switzerland whose farmers value the new technologies' contribution on farm sustainability, New Zealand farmers are more concerned with the effects of international trade and government interventions on the sustainability of farming.

A more widely accepted understanding in the literature shows that agricultural sustainability should consider the effectiveness of ecological, economic and social environmental sustainability (Ikerd, 2006; Van Cauwenbergh et al., 2007; Sydorovych \& Wossink, 2008). Similar to our study, Van Calker et al. (2005) examined how a Dutch dairy farm's farming activities affected its economic, internal social, external social and ecological sustainability. Their study concluded that food safety is ranked as the top external social concern; ground water pollution and soil dehydration are ranked as two important environmental concerns; profitability is the only economic concern of the dairy farm. The same study also pointed out that internal social sustainability focuses on the working conditions of farm workers while external social sustainability deals with societal concerns on the impact of agriculture on the wellness of humans and animals (Van Calker et al., 2005). Ikerd (2006) pointed out that agricultural sustainability refers to food production system's ability to renew production resources and generate 
income. Lien, Hardaker, and Flaten (2007) used crop production data gathered in Norway to conclude that organic farming is less economic sustainable than conventional farming, when the government subsidies are not available.

Another important aspect of agricultural sustainability is social agriculture. Macri and Perito (2009) discussed a case study of social agriculture in Italy. In their study, they defined social agriculture as a possible means to diversify farming and agriculture so that it can improve the quality of life in rural areas and even support the lives of disabled, weak and/or socially excluded citizen. The authors identify the following organizations that support social agriculture in Italy: "A" Social Cooperatives (non for profit, activities on farming and education), "B" Social Cooperatives (non for profit, activities on labor integration, socio recreation among others), Private farms (for profits), Public Institutes.

In the context of economic and rural development, FAO (Food and Agriculture Organization of the U.N.) provides an even wider definition of agriculture sustainability that further incorporates the social aspect. According to FAO sustainable agriculture and rural development (SARD) can be defined as: "the management and conservation of the natural resource base and the orientation of technological and institutional change in such a manner as to ensure the attainment and continued satisfaction of human needs for present and future generations. Such sustainable development (in the agriculture, forestry and fisheries sectors) conserves land, water, plant and animal genetic resources, is environmentally non-degrading, technically appropriate, economically viable and socially acceptable (FAO, 1989). According to FAO the emphasis at the core of this definition is the "welfare of humans, living now and not yet born".

\section{Data}

The educational program was made available to 87 agribusiness students enrolled in an agribusiness management class in a California State University campus in fall, 2012. The program included three continued lectures taught during the third week in October 2012; these lectures focused on agricultural sustainability in California. After a 30-minute lecture, a 15-minute Q\&A session was provided. The lectures and the session-covered topics are listed in Table 1. The course instructor used Power Point slides to cover the first lecture. Two guest speakers, a professor in agriculture industrial organization and a lecturer in viticulture science, instructed the second and the third lectures, respectively. An online survey of 24 questions was administered before and after educational program (early October and late October through December). Students were given bonus points for completion of the surveys by a specified due date. Of the 87 students taking the class, 56 participated in the pre-survey and 53 in the post-survey, for a total of 109 responses, and a total of 46 students completed both surveys.

Table 1. Lectures covered in the educational program

\begin{tabular}{|c|c|c|c|}
\hline Topics & Lecture 1 & Lecture 2 & Lecture 3 \\
\hline 1 & The three spheres of sustainability & $\begin{array}{l}\text { Sustainable agriculture and the use of } \\
\text { green energy in California }\end{array}$ & $\begin{array}{l}\text { Sustainable grape production in } \\
\text { California: water and soil quality }\end{array}$ \\
\hline 2 & $\begin{array}{l}\text { The USDA definition of sustainable } \\
\text { agriculture }\end{array}$ & $\begin{array}{l}\text { California wind farms and the use of } \\
\text { solar power in production agriculture }\end{array}$ & $\begin{array}{l}\text { The economics of a high yielding } \\
\text { grape pruning method }\end{array}$ \\
\hline 3 & $\begin{array}{l}\text { Organic farming, food safety, and } \\
\text { the future of food }\end{array}$ & $\begin{array}{l}\text { The economics of building farm level } \\
\text { ethanol plant in California }\end{array}$ & $\begin{array}{l}\text { Long-term profitability of California } \\
\text { grape production }\end{array}$ \\
\hline 4 & $\begin{array}{l}\text { Farm profitability, environmental } \\
\text { stewardship and quality of farm } \\
\text { family life }\end{array}$ & & \\
\hline
\end{tabular}

Respondents' demographics appear in Table 2. A similar number of female and male participated in the study. Eighty-nine percent of the respondents are between 19 and 24 years old; over $70 \%$ of them are White and about $10 \%$ are Hispanic. About $60 \%$ of the participants are graduating seniors and about $40 \%$ are juniors, majored in plant science, animal science, agribusiness, agricultural education and agricultural mechanics. More than $50 \%$ of the respondents reported an annual household income of $\$ 49,000$ or less; $20 \%$ of them have an income between $\$ 50,000$ and $\$ 99,999$ with only a small percentage of the respondents (about $14 \%$ ) reporting high income of $\$ 200,000$ and up. Most of the respondents have some farming background: about $50 \%$ of them have worked in farming for 1-6 years and $22 \%$ of them have worked in the agricultural industry for 16 years or more. At first glance this finding seems untrue given the young age of the respondents. However, additional conversations 
with the participants revealed that many of them own a family farm and they consider themselves as having been working in the industry since their childhood. About $50 \%$ of them have a family owned fruit, animal, or vegetable farm. About $50 \%$ of them live in rural areas; $25 \%$ live in city or urban areas; and the rest live in suburban areas.

Table 2. Demographics

\begin{tabular}{|c|c|c|c|c|c|c|}
\hline & \multicolumn{2}{|c|}{ Entire sample } & \multicolumn{2}{|c|}{ Pre-survey } & \multicolumn{2}{|c|}{ Post-survey } \\
\hline & Count & $\%$ & Count & $\%$ & Count & $\%$ \\
\hline \multicolumn{7}{|l|}{ Gender } \\
\hline female & 50 & $49 \%$ & 25 & $49 \%$ & 25 & $48 \%$ \\
\hline male & 53 & $51 \%$ & 26 & $51 \%$ & 27 & $52 \%$ \\
\hline Total & 103 & $100 \%$ & 51 & $100 \%$ & 52 & $100 \%$ \\
\hline \multicolumn{7}{|l|}{ Age } \\
\hline $19-20$ & 24 & $25 \%$ & 12 & $28 \%$ & 12 & $23 \%$ \\
\hline $21-22$ & 38 & $40 \%$ & 15 & $35 \%$ & 23 & $43 \%$ \\
\hline $23-24$ & 23 & $24 \%$ & 11 & $26 \%$ & 12 & $23 \%$ \\
\hline 25 or older & 11 & $11 \%$ & 5 & $11 \%$ & 6 & $11 \%$ \\
\hline Total & 96 & $100 \%$ & 43 & $100 \%$ & 53 & $100 \%$ \\
\hline \multicolumn{7}{|l|}{ Race } \\
\hline white & 79 & $74 \%$ & 39 & $73 \%$ & 40 & $75 \%$ \\
\hline Hispanic & 14 & $13 \%$ & 6 & $11 \%$ & 8 & $15 \%$ \\
\hline multi & 6 & $6 \%$ & 4 & $8 \%$ & 2 & $4 \%$ \\
\hline Alaska & 4 & $4 \%$ & 2 & $4 \%$ & 2 & $4 \%$ \\
\hline Asia & 2 & $2 \%$ & 1 & $2 \%$ & 1 & $2 \%$ \\
\hline black & 1 & $1 \%$ & 1 & $2 \%$ & 0 & \\
\hline Total & 106 & $100 \%$ & 53 & $100 \%$ & 53 & $100 \%$ \\
\hline \multicolumn{7}{|c|}{ Student classification } \\
\hline senior & 62 & $58 \%$ & 32 & $59 \%$ & 30 & $57 \%$ \\
\hline junior & 43 & $40 \%$ & 21 & $39 \%$ & 22 & $41 \%$ \\
\hline Sophomore & 2 & $2 \%$ & 1 & $2 \%$ & 1 & $2 \%$ \\
\hline Total & 107 & $100 \%$ & 54 & $100 \%$ & 53 & $100 \%$ \\
\hline \multicolumn{7}{|c|}{ Annual household income } \\
\hline$\$ 0-24,999$ & 42 & $41 \%$ & 19 & $39 \%$ & 23 & $44 \%$ \\
\hline$\$ 25,000-49,000$ & 16 & $16 \%$ & 8 & $16 \%$ & 8 & $15 \%$ \\
\hline$\$ 50,000-74,999$ & 12 & $12 \%$ & 6 & $12 \%$ & 6 & $12 \%$ \\
\hline$\$ 75,000-99,999$ & 8 & $8 \%$ & 4 & $8 \%$ & 4 & $8 \%$ \\
\hline$\$ 100,000-124,999$ & 3 & $3 \%$ & 2 & $4 \%$ & 1 & $2 \%$ \\
\hline$\$ 125,000-149,000$ & 4 & $4 \%$ & 3 & $6 \%$ & 1 & $2 \%$ \\
\hline$\$ 150,000-174,999$ & 1 & $1 \%$ & 0 & $0 \%$ & 1 & $2 \%$ \\
\hline$\$ 175,000-199,999$ & 1 & $1 \%$ & 0 & $0 \%$ & 1 & $2 \%$ \\
\hline$\$ 200,000$ and up & 14 & $14 \%$ & 7 & $14 \%$ & 7 & $13 \%$ \\
\hline Total & 101 & 1 & 49 & $100 \%$ & 53 & $100 \%$ \\
\hline \multicolumn{7}{|l|}{ Years in farming } \\
\hline 0 & 7 & $7 \%$ & 0 & $0 \%$ & 7 & $13 \%$ \\
\hline $1-3$ years & 28 & $29 \%$ & 12 & $29 \%$ & 16 & $30 \%$ \\
\hline 4-6 years & 18 & $19 \%$ & 10 & $24 \%$ & 8 & $15 \%$ \\
\hline $7-9$ years & 9 & $10 \%$ & 0 & $0 \%$ & 9 & $17 \%$ \\
\hline $10-12$ years & 8 & $9 \%$ & 5 & $12 \%$ & 3 & $6 \%$ \\
\hline $13-15$ years & 4 & $4 \%$ & 2 & $5 \%$ & 2 & $4 \%$ \\
\hline 16 years and more & 21 & $22 \%$ & 13 & $31 \%$ & 8 & $15 \%$ \\
\hline Total & 95 & $100 \%$ & 42 & $100 \%$ & 53 & $100 \%$ \\
\hline \multicolumn{7}{|l|}{ Have a family farm } \\
\hline Yes & 48 & $49 \%$ & 23 & $50 \%$ & 25 & $47 \%$ \\
\hline No & 51 & $51 \%$ & 23 & $50 \%$ & 28 & $53 \%$ \\
\hline Total & 99 & $100 \%$ & 46 & $100 \%$ & 53 & $100 \%$ \\
\hline
\end{tabular}




\begin{tabular}{|c|c|c|c|c|c|c|}
\hline \multicolumn{7}{|l|}{ Family farm type } \\
\hline I do not have a farm & 46 & $51 \%$ & 22 & $58 \%$ & 24 & $46 \%$ \\
\hline A fruit farm & 12 & $13 \%$ & 6 & $16 \%$ & 6 & $12 \%$ \\
\hline An animal farm & 19 & $21 \%$ & 5 & $13 \%$ & 14 & $27 \%$ \\
\hline A vegetable farm & 6 & $8 \%$ & 3 & $8 \%$ & 3 & $6 \%$ \\
\hline Other & 7 & $7 \%$ & 2 & $5 \%$ & 5 & $10 \%$ \\
\hline Total & 90 & $100 \%$ & 38 & $100 \%$ & 52 & $100 \%$ \\
\hline \multicolumn{7}{|l|}{ Type of community live } \\
\hline Rural & 46 & $49 \%$ & 20 & $50 \%$ & 26 & $49 \%$ \\
\hline City or urban & 23 & $25 \%$ & 10 & $25 \%$ & 13 & $24 \%$ \\
\hline Suburban & 22 & $24 \%$ & 10 & $25 \%$ & 12 & $23 \%$ \\
\hline Other & 2 & $2 \%$ & 0 & $0 \%$ & 2 & $4 \%$ \\
\hline Total & 93 & $100 \%$ & 40 & $100 \%$ & 53 & $100 \%$ \\
\hline \multicolumn{7}{|c|}{ Most important energy in 10 years } \\
\hline Solar & 50 & $48 \%$ & 27 & $54 \%$ & 23 & $43 \%$ \\
\hline Ethanol & 15 & $15 \%$ & 9 & $18 \%$ & 6 & $11 \%$ \\
\hline Gas & 14 & $14 \%$ & 6 & $12 \%$ & 8 & $15 \%$ \\
\hline Wind & 11 & $11 \%$ & 3 & $6 \%$ & 8 & $15 \%$ \\
\hline Nuclear & 9 & $8 \%$ & 3 & $6 \%$ & 6 & $11 \%$ \\
\hline Coal & 4 & $4 \%$ & 2 & $4 \%$ & 2 & $4 \%$ \\
\hline Total & 103 & $100 \%$ & 50 & $100 \%$ & 53 & $100 \%$ \\
\hline \multicolumn{7}{|l|}{ Pollution restriction law } \\
\hline Much more strict & 5 & $5 \%$ & 3 & $5 \%$ & 2 & $4 \%$ \\
\hline Somewhat more strict & 5 & $5 \%$ & 2 & $4 \%$ & 3 & $6 \%$ \\
\hline Slightly more strict & 23 & $21 \%$ & 15 & $27 \%$ & 8 & $15 \%$ \\
\hline About the same as now & 38 & $35 \%$ & 18 & $33 \%$ & 20 & $38 \%$ \\
\hline Slightly less strict & 19 & $18 \%$ & 11 & $20 \%$ & 8 & $15 \%$ \\
\hline Somewhat less strict & 10 & $9 \%$ & 6 & $11 \%$ & 4 & $8 \%$ \\
\hline Much less strict & 8 & $7 \%$ & 0 & $0 \%$ & 8 & $15 \%$ \\
\hline Total & 108 & $100 \%$ & 55 & $100 \%$ & 53 & $100 \%$ \\
\hline \multicolumn{7}{|c|}{ Willingness to change lifestyle to reduce environmental impact } \\
\hline Extremely willing & 2 & $2 \%$ & 1 & $2 \%$ & 1 & $2 \%$ \\
\hline Very willing & 21 & $20 \%$ & 10 & $18 \%$ & 11 & $21 \%$ \\
\hline Moderately wiling & 49 & $45 \%$ & 27 & $49 \%$ & 22 & $42 \%$ \\
\hline Slightly willing & 27 & $25 \%$ & 12 & $22 \%$ & 15 & $28 \%$ \\
\hline Not at all willing & 9 & $8 \%$ & 5 & $9 \%$ & 4 & $8 \%$ \\
\hline Total & 108 & $100 \%$ & 55 & $100 \%$ & 53 & $100 \%$ \\
\hline
\end{tabular}

In the questionnaire, we asked respondents to select, out of a list of seven alternative energy sources, their perceived most important energy source in the future 10 years. Solar was the most selected source of energy, followed by ethanol and gas. We then asked their opinions on the current pollution restriction laws. A little over one third of the respondents believed that pollution restriction laws should be about as strict as they are now; while one third of them believed the laws should be stricter, and the rest believed the laws should be less strict. Different from the pre-survey of $20 \%$, in the post-survey, $15 \%$ of the respondents believed that laws should be less strict. About $10 \%$ of the respondents from both surveys indicate that they are not at all willing to change lifestyle to reduce any environmental impact. But about $70 \%$ of them tended to be willing to change their life style to help the environment.

Respondents were asked to rate different attributes of agribusiness sustainability by allocating 100 points to selected attributes of economic, internal social, external social and environmental sustainability. Results are presented in Table 3. For economic sustainability, Income stability and prospects for long-run profits are the top two attributes. Reliance on government subsidies and adherence to government regulations are the two least selected features. Though the two production costs related features, i.e., the ability to pay for fertilizer, pesticides and fuel, and sufficient cash to pay labor and manager, are rated slightly lower than the income and profit attributes, their ratings are clearly higher than government subsidies and regulations. Ratings for the internal social sustainability show that continuity of farm in the family is considered the most important attribute. Thus, 
participants believed that to achieve internal social sustainability, the family should continuously own the farm. Participants also considered it important to help farmers reduce health risk when applying agricultural chemicals.

Table 3. Ratings of selected attributes

\begin{tabular}{|c|c|c|c|c|c|c|}
\hline & \multicolumn{2}{|c|}{ Entire sample } & \multicolumn{2}{|c|}{ Pre-survey } & \multicolumn{2}{|c|}{ Post -Survey } \\
\hline \multicolumn{7}{|l|}{ Economic sustainability } \\
\hline & Count & Mean & Count & Mean & Count & Mean \\
\hline Income stability & 104 & 21.22 & 52 & 20.33 & 52 & 22.12 \\
\hline Prospects for long-run profit & 105 & 20.00 & 52 & 19.83 & 53 & 20.17 \\
\hline Ability to pay for fertilizer, pesticides, fuel & 105 & 16.90 & 52 & 17.96 & 53 & 18.94 \\
\hline Sufficient cash to pay labor and managers & 105 & 18.23 & 52 & 17.52 & 53 & 15.87 \\
\hline Reliance on government subsidies & 105 & 10.86 & 52 & 13.92 & 53 & $11.45^{*}$ \\
\hline Adherence to government regulations & 105 & 13.16 & 52 & 10.25 & 53 & $12.42 *$ \\
\hline \multicolumn{7}{|l|}{ Internal social sustainability } \\
\hline Continuity of the farm in the family & 106 & 28.44 & 54 & 30.46 & 52 & 26.35 \\
\hline $\begin{array}{l}\text { Reduced health risk of applying agricultural } \\
\text { chemicals }\end{array}$ & 106 & 26.06 & 54 & 26.44 & 52 & 25.67 \\
\hline Reduced physical stress of farmers & 106 & 22.30 & 54 & 21.46 & 52 & $23.17^{*}$ \\
\hline Reduced mental stress of farmers & 106 & 22.48 & 54 & 21.17 & 52 & $23.85^{*}$ \\
\hline \multicolumn{7}{|l|}{ External social sustainability } \\
\hline Produce safe food & 107 & 21.47 & 54 & 22.78 & 53 & $20.13^{*}$ \\
\hline Produce high quality food & 107 & 20.39 & 54 & 24.28 & 53 & $16.43^{*}$ \\
\hline Take good care of farm animals & 107 & 15.50 & 54 & 15.94 & 53 & 15.06 \\
\hline Contribute to local economy & 107 & 13.21 & 54 & 13.35 & 53 & $13.07 *$ \\
\hline $\begin{array}{l}\text { Maintain good relationship with surrounding } \\
\text { communities }\end{array}$ & 107 & 13.51 & 54 & 12.35 & 53 & $14.70^{*}$ \\
\hline Protect public recreational resources & 106 & 11.06 & 53 & 10.06 & 53 & 12.06 \\
\hline Prevent farm odor and noise & 107 & 8.86 & 54 & 8.28 & 53 & 9.45 \\
\hline \multicolumn{7}{|l|}{ Environmental sustainability } \\
\hline Improve soil quality & 106 & 17.38 & 53 & 18.84 & 53 & $15.92 *$ \\
\hline Improve water quality & 106 & 17.36 & 53 & 18.38 & 53 & $16.34 *$ \\
\hline Improve natural resource use efficiency & 106 & 15.44 & 53 & 14.87 & 53 & $16.02 *$ \\
\hline Improve air quality & 106 & 13.77 & 53 & 13.38 & 53 & 14.17 \\
\hline Reduce solid waste disposal & 106 & 12.38 & 53 & 11.97 & 53 & 12.79 \\
\hline Reduce greenhouse gas emission & 106 & 12.01 & 53 & 11.46 & 53 & 12.57 \\
\hline Enhance biodiversity & 106 & 11.47 & 53 & 11.19 & 53 & 11.75 \\
\hline
\end{tabular}

Note. $*$ Post-survey rank of importance rating was different from the pre-survey.

We find that the educational program impacted respondents' attributes ratings. For example, our results show that the impact of the educational program is more significant on the ratings of the external social and environmental sustainability than on economic and internal social sustainability. The produce high quality food feature is rated the highest in the pre-survey but the second highest in the post-survey. In the post-survey, the produce safe food feature is rated the highest. Thus, after participating in the educational program, respondents became more likely to consider food safety, rather than the overall quality of food, as the most important feature in agricultural external social sustainability. This might be a result of an extensive discussion about food safety during the first lecture. In this lecture, respondents were asked to discuss organic farming in California and to list reasons why organic farming is more environmentally friendly and why organic vegetable and fruits are safer to eat than conventional alternatives. In both the pre-and post survey, prevent farm odor and noise is rated the least important feature. In the environmental sustainability ratings, improve soil quality is considered the most important in the pre-survey but the second most important in the post-survey. In the post-survey, improve water quality is rated the most important. This again may be a result of the educational program, during the third lecture; water and soil quality related topics were provided to help students understand the importance of irrigation and good quality soil on grape profitability. 


\section{Model}

A choice-based conjoint ( $\mathrm{CBC}$ ) analysis is used to gather survey takers' opinions towards sustainable agriculture. The CBC framework was first developed in 1981 by marketing researchers to predict the probability that an individual consumer will choose the preferred product out of various frequently purchased alternatives (Batsell \& Lodish, 1981). Sydorovych and Wossink (2008) first applied the CBC method to predict the probability that an agriculture shareholder chooses between two sustainable profiles, each representing different utility outcomes. Selection of attributes and attributes levels is a difficult task given that the range of sustainability attributes is wide. This study includes eight attributes and two levels for each attribute. Van Calker et al. (2005) identified five attributes each for external social and ecological sustainability. Later, Sydorovych and Wossink (2008) included four or more levels in each sustainability attribute. One drawback of including more than two attribute levels is, the more attribute levels are selected the larger the experimental designs. This makes the survey lengthy and rather complex. Thus, large experimental designs do not necessarily perform better than designs with a smaller choice set (Lusk \& Norwood, 2005).

To reduce the burden of survey respondents and obtain a better response rate, this study only chooses two attributes for each sustainability attribute. The attributes included are selected from Sydorovych and Wossink (2008) and Van Calker et al. (2005). We rely on these two studies because in both cases the authors conducted extensive discussions with industrial experts, researchers, governmental agencies, non-governmental environmental agencies, and farmers to define the attributes. Our attributes and their levels are presented in Figure 1 and a sample choice card is shown in Figure 2.

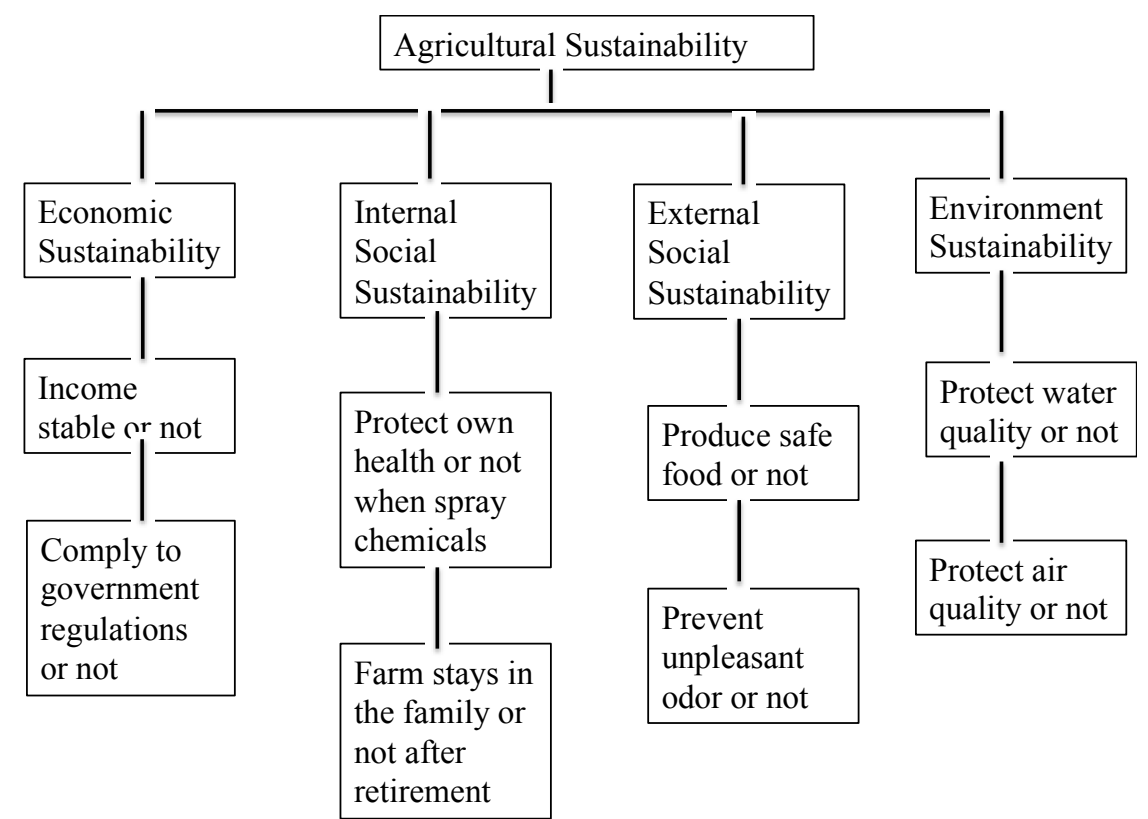

Figure 1. Selected attributes and attributes levels

\begin{tabular}{|c|c|c|c|c|c|c|c|c|c|}
\hline Choices & Income & $\begin{array}{l}\text { Government } \\
\text { regulation }\end{array}$ & & $\begin{array}{l}\text { Food } \\
\text { safety }\end{array}$ & Odor & $\begin{array}{l}\text { Water } \\
\text { quality }\end{array}$ & $\begin{array}{l}\text { Air } \\
\text { quality }\end{array}$ & $\begin{array}{l}\text { Farmer } \\
\text { health }\end{array}$ & $\begin{array}{l}\text { Farm } \\
\text { continuity }\end{array}$ \\
\hline 1 & $\begin{array}{l}\text { Unstable } \\
\text { income }\end{array}$ & $\begin{array}{l}\text { Comply } \\
\text { government } \\
\text { regulations }\end{array}$ & to & $\begin{array}{l}\text { Cannot } \\
\text { produce } \\
\text { safe food }\end{array}$ & $\begin{array}{l}\text { Prevent } \\
\text { unpleasant } \\
\text { odor }\end{array}$ & $\begin{array}{l}\text { Do not } \\
\text { protect } \\
\text { water } \\
\text { quality }\end{array}$ & $\begin{array}{l}\text { Do not } \\
\text { protect } \\
\text { air } \\
\text { quality }\end{array}$ & $\begin{array}{l}\text { Protect own } \\
\text { health when } \\
\text { spray } \\
\text { chemicals }\end{array}$ & $\begin{array}{l}\text { Farm stays in } \\
\text { the family } \\
\text { after } \\
\text { retirement }\end{array}$ \\
\hline 2 & $\begin{array}{l}\text { Stable } \\
\text { income }\end{array}$ & $\begin{array}{l}\text { Comply } \\
\text { government } \\
\text { regulations }\end{array}$ & to & $\begin{array}{l}\text { Produce } \\
\text { safe food }\end{array}$ & $\begin{array}{l}\text { Do not } \\
\text { prevent } \\
\text { unpleasant } \\
\text { odor }\end{array}$ & $\begin{array}{l}\text { Do not } \\
\text { protect } \\
\text { water } \\
\text { quality }\end{array}$ & $\begin{array}{l}\text { Protect } \\
\text { air } \\
\text { quality }\end{array}$ & $\begin{array}{l}\text { Protect own } \\
\text { health when } \\
\text { spray } \\
\text { chemicals }\end{array}$ & $\begin{array}{l}\text { Farm stays in } \\
\text { the family } \\
\text { after } \\
\text { retirement }\end{array}$ \\
\hline
\end{tabular}

Figure 2. A sample card 
To conduct the econometric estimation, this study applies a conditional logit model. McFadden (1974) defined in the conditional logit model that the probability $P_{i j}$ that individual $i$ will choose alternative $j$ from choice set $C$ is the probability that the utility associated with choice $j$ is greater than the utility associated with all other $k$ choices in the same choice set. Thus,

$$
\begin{aligned}
& P_{i j}=P\left(\beta x_{i j}+\varepsilon_{i j}>\beta x_{i k}+\varepsilon_{i k}\right) \\
& P_{i j}=P\left(\varepsilon_{i j}-\varepsilon_{i k}>\beta x_{i j}-\beta x_{i k}\right), j \neq k
\end{aligned}
$$

Assume the error terms $\varepsilon$ are independent and identically distributed with the Weibull (Gnedenko, extreme value) distribution (McFadden, 1974), $P_{i j}$ is:

$$
P_{i j}=\frac{\exp \left(\beta x_{i j}\right)}{\sum_{k=1}^{j} \exp \left(\beta x_{i k}\right)}
$$

In the above model, $x$ is a vector of product attributes and the model assumes that the characteristics of respondents are the same across the sample. The conditional logit model is based on the random utility theory of Lancaster (1966). According to Lancaster, the utility of the $i$ th consumer $\mathrm{U}_{i}(i=1, \ldots, I)$ derived from the $j$ th alternative (out of a choice set of $C$ ) is a function of the selected attributes of the alternative $j$ :

$$
U_{i j}=\beta x_{i j}+\varepsilon_{i j}
$$

Where $\beta$ is a vector of unknown parameters of interest, $x$ is a vector of attributes for product $j$ selected by consumer $i$, and $\varepsilon$ is a stochastic error term resulted from measurements errors.

Utility is estimated as follows:

$$
\begin{aligned}
\text { Utility } & =\beta_{1}(\text { Income })+\beta_{2}(\text { government })+\beta_{3}(\text { food safety })+\beta_{4}(\text { farmodor }) \\
& +\beta_{5}(\text { water quality })+\beta_{6}(\text { air quality })+\beta_{7}(\text { farmer health })+\beta_{8}(\text { farm continuity })
\end{aligned}
$$

The first two variables, income and government, estimate the impact of economic sustainability on derived utility. The food safety and farm odor variables estimate the impact of external social sustainability; the water quality and air quality variables estimate the impact of environmental sustainability; and the farm health and farm continuity variables estimate the impact of internal social sustainability on the derived utility.

\section{Results}

STATA 11 econometric software was used to estimate the models. Table 4 shows the results of the conditional

\begin{tabular}{|c|c|c|c|c|c|c|c|}
\hline \multirow[b]{2}{*}{ Variables } & \multirow[b]{2}{*}{ Definition } & \multicolumn{3}{|c|}{ Estimation results } & \multicolumn{3}{|c|}{ Directly stated } \\
\hline & & $\begin{array}{l}\text { Entire } \\
\text { sample }\end{array}$ & Pre-survey & Post survey & $\begin{array}{l}\text { Entire } \\
\text { sample }\end{array}$ & Pre-survey & $\begin{array}{l}\text { Post } \\
\text { survey }\end{array}$ \\
\hline Income & 1 if stable income; 0 unstable & $\begin{array}{l}1.020 * * * \\
(0.111)\end{array}$ & $\begin{array}{l}1.151^{* * *} \\
(0.160)\end{array}$ & $\begin{array}{l}0.893 * * * \\
(0.154)\end{array}$ & $\begin{array}{l}21.221 \\
(16.697)\end{array}$ & $\begin{array}{l}20.326 \\
(16.634)\end{array}$ & $\begin{array}{l}22.158 \\
(16.759)\end{array}$ \\
\hline Government & $\begin{array}{l}1 \text { if comply to government } \\
\text { regulation; } 0 \text { otherwise }\end{array}$ & $\begin{array}{l}-0.001 \\
(0.112)\end{array}$ & $\begin{array}{l}-0.001 \\
(0.161)\end{array}$ & $\begin{array}{l}-0.006 \\
(0.154)\end{array}$ & $\begin{array}{l}10.857 \\
(16.697)\end{array}$ & $\begin{array}{l}10.250 \\
(16.634)\end{array}$ & $\begin{array}{l}12.420 \\
(16.759)\end{array}$ \\
\hline Food safety & $\begin{array}{l}1 \text { if produce safe food; } 0 \\
\text { otherwise }\end{array}$ & $\begin{array}{l}1.679 * * * \\
(0.110)\end{array}$ & $\begin{array}{l}1.854 * * * \\
(0.160)\end{array}$ & $\begin{array}{l}1.512 * * * \\
(0.154)\end{array}$ & $\begin{array}{l}21.467 \\
(24.823)\end{array}$ & $\begin{array}{l}22.780 \\
(15.283)\end{array}$ & $\begin{array}{l}20.132 \\
(14.415)\end{array}$ \\
\hline Farm odor & $\begin{array}{l}1 \text { if prevent unpleasant odor; } \\
0 \text { otherwise }\end{array}$ & $\begin{array}{l}0.605^{* * *} \\
(0.110)\end{array}$ & $\begin{array}{l}0.669 * * * \\
(0.159)\end{array}$ & $\begin{array}{l}0.546 \quad * * * \\
(0.154)\end{array}$ & $\begin{array}{l}8.859 \\
(24.823)\end{array}$ & $\begin{array}{l}8.278 \\
(15.283)\end{array}$ & $\begin{array}{l}9.454 \\
(14.415)\end{array}$ \\
\hline Water quality & 1 if protect water quality; 0 & $0.707 * * *$ & $0.690 * * *$ & $0.719 * * *$ & 17.361 & 18.383 & 16.344 \\
\hline
\end{tabular}
logit model. The likelihood ratio test, $\mathrm{LR} \mathrm{chi}{ }^{2}$ and the $\mathrm{prob}>\mathrm{chi}^{2}$ scores suggest that the selected variables for the conditional logit model explain the variations in the dependent variable, participant's derived utility. If a selected variable is significant, it remains significant across the three estimations of either using the entire sample, or using the pre-survey sample or the post-survey sample (alpha $<1 \%$ ).

Table 4. Results of the main effect model and the directly stated preference 


\begin{tabular}{llllllll}
\hline & otherwise & $(0.111)$ & $(0.160)$ & $(0.154)$ & $(14.849)$ & $(14.229)$ & $(14.223)$ \\
\multirow{2}{*}{ Air quality } & $\begin{array}{l}1 \text { if protect air quality; } \\
\text { otherwise }\end{array}$ & -0.099 & -0.091 & -0.107 & 13.776 & 18.383 & 14.172 \\
& $(0.110)$ & $(0.158)$ & $(0.154)$ & $(14.849)$ & $(14.229)$ & $(14.223)$ \\
Farmer & $\begin{array}{l}1 \text { if protect farmer health } \\
\text { when spray chemicals; }\end{array}$ & -0.004 & 0.011 & -0.017 & 26.066 & 26.444 & 25.674 \\
health & $\begin{array}{l}(0.111) \\
\text { otherwise }\end{array}$ & $(0.159)$ & $(0.154)$ & $(14.261)$ & $(24.884)$ & $(24.759)$ \\
Farm & $\begin{array}{l}\text { 1 if farm stays in the family; } \\
\text { continuity }\end{array}$ & $0.749^{* * *}$ & $0.811^{* * *}$ & $0.693^{* * *}$ & 28.443 & 30.463 & 26.346 \\
$\begin{array}{l}\text { Likelihood } \\
\text { ratio }\end{array}$ & & $(0.111)$ & $(0.160)$ & $(0.154)$ & $(14.261)$ & $(24.884)$ & $(24.759)$ \\
Prob>chi2 & & 481 & 282 & 203 & -- & -- & -- \\
Pseudo-R2 & $<0.0001$ & $<0.0001$ & $<0.0001$ & -- & -- & -- \\
\hline
\end{tabular}

Note. Asterisks $(* * *)$ indicates coefficients significantly different from zero at alfa $=0.01$ level. The first number of the estimation results is the coefficient and the number in parentheses is standard error. The first number of the directly stated results is the mean attribute and the number in parenthesis is the mean of all selected attributes in that category.

Of the two economic sustainability variables, income contributes significantly and positively to the derived utility (Table 4). To quantify the impact of income on the probability of choosing a card, marginal effect is computed. Table 5 shows the estimation of the marginal effects from the main model. The first row of Table 5 shows that, the probability of being chosen is $8.4 \%$ higher if a card states income is stable than a card that states income is unstable, holding all other variables constant at the mean level. This result is consistent with the directly stated mean importance rating of 21.22 for the income variable (Table 4), which is significantly higher than the category mean of 16.63; where income was ranked as the top economic sustainable attribute. The two external social sustainability attributes are both significant, indicating that respondents value the producing safe food and the preventing unpleasant odor attributes of sustainable farming (Table 4). The respondents believed that to be externally social sustainable, farming should supply safe food and should prevent unpleasant odor. The marginal effect reveals that the probability is $14 \%$ higher if a card says producing food safety than a card without it (Table 5). The impact of farm odor variable is significant and positive on derived utility. However, the overall rating of farm odor attribute is significantly lower than the category average. Thus, the perceived importance rating does not reflect the impact of this variable on the derived utility.

Of the two selected environmental sustainability attributes, the water quality attribute contributes significantly to the derived utility (Table 4). This attribute was also rated at 17.36, higher than the category mean of 14.85. The probability of choosing a card with this attribute is $6 \%$ higher than a card without this attribute. The farm continuity attribute also has a significant impact on derived utility (Table 4).

Table 5. Marginal effects of the main effect model

\begin{tabular}{|c|c|c|c|c|}
\hline & & Entire sample & Pre-survey & Post-survey \\
\hline Variables & Definition & Coefficient & Coefficient & Coefficient \\
\hline Income & 1 if stable income; 0 unstable & $0.084 * * *(0.011)$ & $0.080 * * *(0.015)$ & $0.087 * * *(0.017)$ \\
\hline Government & 1 if comply to government regulation; 0 otherwise & $0(0.001)$ & $0(0.011)$ & $0(0.015)$ \\
\hline Food safety & 1 if produce safe food; 0 otherwise & $0.144 * * *(0.016)$ & $0.135 * * *(0.022)$ & $0.151 * * *(0.023)$ \\
\hline Farm odor & 1 if prevent unpleasant odor; 0 otherwise & $0.049 * * *(0.008)$ & $0.046 * * *(0.012)$ & $0.053 * * *(0.014)$ \\
\hline Water quality & 1 if protect water quality; 0 otherwise & $0.058 * * *(0.001)$ & $0.047 * * *(0.012)$ & $0.070^{* * *}(0.016)$ \\
\hline Air quality & 1 if protect air quality; 0 otherwise & $-0.008(0.001)$ & $-0.006(0.011)$ & $-0.010(0.015)$ \\
\hline Farmer health & 1 if protect farmer health when spray chemicals; 0 otherwise & $0(0.001)$ & $0.001(0.011)$ & $-0.001(0.015)$ \\
\hline Farm continuity & 1 if farm stays in the family; 0 otherwise & $0.061 * * *(0.010)$ & $0.056 * * *(0.013)$ & $0.067 * * *(0.016)$ \\
\hline
\end{tabular}

Note. Asterisks $(* * *)$ indicates coefficients significantly different from zero at alfa $=0.01$ level. The first number of the estimation results is the coefficient and the number in parentheses is standard error. 
To better understand the impact of income on economic sustainability perception, the income variable is multiplied by family farm variable to generate an interaction term. This interaction term is added as a new explanatory variable to the conditional logit model. Table 6 shows the main results. All the previously included attributes retain the same sign and significance level. The interaction term is positive and significant at a $10 \%$ level. If a respondent owns a family farm, the probability of him/her selecting a card that says stable income is $3 \%$ higher than those without a family farm. This interaction term is not significant in the pre-survey sample but becomes significant in the post-survey sample (alpha $<5 \%$ ). Thus, before participating in the educational program, a respondent with a family farm is less likely to perceive income stability as an important attribute. But after participating in the educational program, a respondent is more likely to consider stable income as an important economic sustainability attribute.

Table 6. Interaction effect model results (family and income)

\begin{tabular}{|c|c|c|c|c|c|c|}
\hline Variables & Entire sample & Marginal effect & Pre-survey & Marginal effect & Post survey & Marginal effect \\
\hline Income & $\begin{array}{l}0.810 * * * \\
(0.158)\end{array}$ & $\begin{array}{l}0.067 * * * \\
(0.014)\end{array}$ & $\begin{array}{l}1.083 * * * \\
(0.246)\end{array}$ & $\begin{array}{l}0.075 * * * \\
(0.020)\end{array}$ & $\begin{array}{l}0.611^{* * *} \\
(0.208)\end{array}$ & $\begin{array}{l}0.058 * * * \\
(0.020)\end{array}$ \\
\hline Government & $\begin{array}{l}0.005 \\
(0.116)\end{array}$ & $\begin{array}{l}0 \\
(0.009)\end{array}$ & $\begin{array}{l}0.017 \\
(0.178)\end{array}$ & $\begin{array}{l}0.001 \\
(0.012)\end{array}$ & $\begin{array}{l}-0.007 \\
(0.155)\end{array}$ & $\begin{array}{l}0 \\
(0.014)\end{array}$ \\
\hline Food safety & $\begin{array}{l}1.688 * * * \\
(0.116)\end{array}$ & $\begin{array}{l}0.147 * * * \\
(0.017)\end{array}$ & $\begin{array}{l}1.902 * * * \\
(0.176)\end{array}$ & $\begin{array}{l}0.139 * * * \\
(0.0247)\end{array}$ & $\begin{array}{l}1.521 * * * \\
(0.154)\end{array}$ & $\begin{array}{l}0.150 * * * \\
(0.023)\end{array}$ \\
\hline Odor & $\begin{array}{l}0.612 * * * \\
(0.116)\end{array}$ & $\begin{array}{l}0.051 * * * \\
(0.009)\end{array}$ & $\begin{array}{l}0.697 * * * \\
(0.176)\end{array}$ & $\begin{array}{l}0.048 * * * \\
(0.012)\end{array}$ & $\begin{array}{l}0.549 * * * \\
(0.154)\end{array}$ & $\begin{array}{l}0.052 * * * \\
(0.014)\end{array}$ \\
\hline Water quality & $\begin{array}{l}0.725^{* * *} \\
(0.116)\end{array}$ & $\begin{array}{l}0.060 * * * \\
(0.011)\end{array}$ & $\begin{array}{l}0.727 * * * \\
(0.176)\end{array}$ & $\begin{array}{l}0.049 * * * \\
(0.014)\end{array}$ & $\begin{array}{l}0.723 * * * \\
(0.254)\end{array}$ & $\begin{array}{l}0.069 * * * \\
(0.016)\end{array}$ \\
\hline Air quality & $\begin{array}{l}-0.121 \\
(0.115)\end{array}$ & $\begin{array}{l}-0.009 \\
(0.01)\end{array}$ & $\begin{array}{l}-0.138 \\
(0.174)\end{array}$ & $\begin{array}{l}-0.009 \\
(0.013)\end{array}$ & $\begin{array}{l}-0.107 \\
(0.154)\end{array}$ & $\begin{array}{l}-0.010 \\
(0.015\end{array}$ \\
\hline Farmer health & $\begin{array}{l}-0.008 \\
(0.116)\end{array}$ & $\begin{array}{l}-0.001 \\
(0.009)\end{array}$ & $\begin{array}{l}0.002 \\
(0.176)\end{array}$ & $\begin{array}{l}0 \\
(0.011)\end{array}$ & $\begin{array}{l}-0.017 \\
(0.154)\end{array}$ & $\begin{array}{l}-0.002 \\
(0.015)\end{array}$ \\
\hline Farm continuity & $\begin{array}{l}0.725^{* * *} \\
(0.116)\end{array}$ & $\begin{array}{l}0.060 * * * \\
(0.011)\end{array}$ & $\begin{array}{l}0.764 * * * \\
(0.177)\end{array}$ & $\begin{array}{l}0.052 * * * \\
(0.014)\end{array}$ & $\begin{array}{l}0.697 * * * \\
(0.154)\end{array}$ & $\begin{array}{l}0.067 * * * \\
(0.016)\end{array}$ \\
\hline $\begin{array}{l}\text { Family Farm and } \\
\text { Income }\end{array}$ & $\begin{array}{l}0.379 * \\
(0.228)\end{array}$ & $\begin{array}{l}0.029 * \\
(0.016)\end{array}$ & $\begin{array}{l}0.079 \\
(0.343)\end{array}$ & $\begin{array}{l}0.005 \\
(0.022)\end{array}$ & $\begin{array}{l}0.609 * * \\
(0.154)\end{array}$ & $\begin{array}{l}0.051^{* *} \\
(0.024)\end{array}$ \\
\hline Likelihood ratio & 439 & -- & 236 & -- & 207 & -- \\
\hline Prob $>$ chi 2 & $<0.0001$ & -- & $<0.0001$ & -- & $<0.0001$ & -- \\
\hline Pseudo-R2 & 0.23 & -- & 0.27 & -- & 0.21 & -- \\
\hline
\end{tabular}

Note. Asterisks $* * *, * *$ and $*$ indicates coefficients significantly different from zero at alfa $=0.01,0.05$ and 0.1 level, respectively. The first number of the estimation results is the coefficient and the number in parentheses is standard error.

Using the same method, the impact of gender and food safety is estimated. The results are shown in Table 7. Results for the entire sample suggest that female respondents are $4 \%$ more likely than male to choose a card that has the 'food safety' attribute. The interaction effect of gender and food safety is significant in the pre-survey sample but become less significant in the post-survey sample. Thus, after attending the educational program, female respondents are less likely to consider the food safety attribute as important. 
Table 7. Interaction effect model results (gender and food safety)

\begin{tabular}{|c|c|c|c|c|c|c|}
\hline Variables & Entire sample & & Pre-survey & & Post survey & \\
\hline & Coefficient & Marginal effect & Coefficient & Marginal effect & Coefficient & Marginal effect \\
\hline Income & $\begin{array}{l}0.983 * * * \\
(0.114)\end{array}$ & $\begin{array}{l}0.079 * * * \\
(0.011)\end{array}$ & $\begin{array}{l}1.143 * * * \\
(0.169)\end{array}$ & $\begin{array}{l}0.076 * * * \\
(0.015)\end{array}$ & $\begin{array}{l}0.845^{* * *} \\
(0.156)\end{array}$ & $\begin{array}{l}0.079 * * * \\
(0.01)\end{array}$ \\
\hline Government & $0.013(0.115)$ & $0.001(0.009)$ & $0.039(0.171)$ & $0.002(0.011)$ & $-0.007(0.157)$ & $0(0.015)$ \\
\hline Food safety & $\begin{array}{l}1.406 * * * \\
(0.152)\end{array}$ & $\begin{array}{l}0.115 * * * \\
(0.017)\end{array}$ & $\begin{array}{l}1.537 * * * \\
(0.224)\end{array}$ & $\begin{array}{l}0.104 * * * \\
(0.002)\end{array}$ & $\begin{array}{l}1.293 * * * \\
(0.210)\end{array}$ & $\begin{array}{l}0.124 * * * \\
(0.025)\end{array}$ \\
\hline Odor & $\begin{array}{l}0.637 * * * \\
(0.114)\end{array}$ & $\begin{array}{l}0.051 * * * \\
(0.008)\end{array}$ & $\begin{array}{l}0.703 * * * \\
(0.167)\end{array}$ & $\begin{array}{l}0.046^{* * * *} \\
(0.011)\end{array}$ & $\begin{array}{l}0.582 * * * \\
(0.156)\end{array}$ & $\begin{array}{l}0.055^{* * * *} \\
(0.014)\end{array}$ \\
\hline Water quality & $\begin{array}{l}0.762 * * * \\
(0.114)\end{array}$ & $\begin{array}{l}0.061 * * * \\
(0.010)\end{array}$ & $\begin{array}{l}0.785 * * * \\
(0.169)\end{array}$ & $\begin{array}{l}0.051 * * * \\
(0.013)\end{array}$ & $\begin{array}{l}0.742 * * * \\
(0.156)\end{array}$ & $\begin{array}{l}0.069 * * * \\
(0.016)\end{array}$ \\
\hline Air quality & $-0.098(0.113)$ & $-0.008(0.009)$ & $-0.113(0.167)$ & $-0.007(0.011)$ & $-0.085(0.156)$ & $-0.008(0.015)$ \\
\hline Farmer health & $-0.015(0.114)$ & $-0.001(0.009)$ & $-0.015(0.167)$ & $0(0.011)$ & $-0.016(0.156)$ & $-0.002(0.015)$ \\
\hline Farm continuity & $\begin{array}{l}0.733 * * * \\
(0.114)\end{array}$ & $\begin{array}{l}0.058 * * * \\
(0.010)\end{array}$ & $\begin{array}{l}0.752 * * * \\
(0.179)\end{array}$ & $\begin{array}{l}0.049 * * * \\
(0.013)\end{array}$ & $\begin{array}{l}0.716 * * * \\
(0.156)\end{array}$ & $\begin{array}{l}0.067 * * * \\
(0.016)\end{array}$ \\
\hline $\begin{array}{l}\text { Gender and food } \\
\text { safety }\end{array}$ & $\begin{array}{l}0.626 * * * \\
(0.224)\end{array}$ & $\begin{array}{l}0.043 * * * \\
(0.014)\end{array}$ & $\begin{array}{l}0.779 * * \\
(0.328)\end{array}$ & $\begin{array}{l}0.043 * * \\
(0.017)\end{array}$ & $\begin{array}{l}0.487 \\
(0.307)\end{array}$ & $\begin{array}{l}0.041 * \\
(0.024)\end{array}$ \\
\hline Likelihood ratio & 470 & -- & 271 & -- & 203 & -- \\
\hline Prob $>$ chi 2 & $<0.001$ & -- & $<0.001$ & -- & $<0.001$ & -- \\
\hline Pseudo-R2 & 0.24 & -- & 0.28 & -- & 0.21 & -- \\
\hline
\end{tabular}

Note. Asterisks $(* * *)\left({ }^{* *}\right)(*)$ indicates coefficients significantly different from zero at alfa $=0.01$ level, 0.05 or 0.1 level, respectively. The first number of the estimation results is the coefficient and the number in parentheses is standard error.

\section{Conclusions and Implications}

This study uses a CBC choice experiment to identify the impact of selected attributes on agribusiness students' perception of agricultural sustainability. We examined students' ratings of the attributes, and analyzed a number of important attributes that significantly affected students' perception. Given the lack of consensus on how to define agricultural sustainability, this study provides insightful information to understand how future California agriculture managers perceive sustainable farming. Our study contributes to the literature by developing an educational program on agricultural sustainability and examining the impact of this program on students' perception of sustainability. Our results indicate that the educational program affects future farm managers' perception of agricultural sustainability in several ways. First, after participating in the educational program, future farm managers' opinion about agricultural external social sustainability changed. Future male managers tended to be more supportive of the idea that farmers should provide safe food to accomplish agricultural external social sustainability. Second, after attending the program future farm managers also tended to view water quality as a more important outcome of agricultural environmental sustainability. Thus, future farm managers are more likely to consider protecting water quality as an important responsibility of farming to achieve environmental sustainability. Third, participating in the educational program helped future managers realize that obtaining a stable income is a key to achieving economic sustainability.

This study simplifies the multi-attribute framework of agricultural sustainability, and identifies the most important attributes that affected future farm managers' opinions. Income stability is found to be an outmost important attribute to economic sustainability perceptions. In contrast, Sydorovych and Wossink (2008) found that income stability does not improve perceptions of economic sustainability. Their study identified long-run profit as the most significant factor changing economic sustainability perceptions. However, profitability is the difference between the value of what a farm produces and the cost of resources it uses or the net farm income. Sydorovych and Wossink (2008) included both income and profit attributes without explaining if income is net income or not, potentially confused survey takers. Our study includes income as the only dollar related attribute, and our participating future farm managers' responses clearly showed that economic sustainability means farm income stability. Producers should achieve a set income goal. If a farm cannot reach the set income goal, the 
farm is not economically sustainable.

In this study we also find that future farm managers view external social sustainability as being able to produce safe food. This finding is consistent with Van Calker et al. (2005). Participating future farm managers believe that providing safe food is a key factor in California's food production. Moreover, participating future farm managers believe unpleasant odor is a negative externality of production agriculture. Being able to prevent the undesirable externality is critical for achieving farm external social sustainability. Moreover, future farm managers pay great attention to water protection, perhaps because of the cost of dealing with wastewater in farming. In contrast, these future farm managers consider protecting air quality a less important attribute. Protecting air quality is considered a responsibility of not only farmers but also the entire society.

\section{References}

Aerni, P. (2002). Stakeholder Attitudes toward the Risk and Benefits of Agricultural Biotechnology in Developing Countries: A Comparison between Mexico and the Philippines. Risk Analysis, 22(6), 1123-1138. http://dx.doi.org/10.1111/1539-6924.00277

Aerni, P. (2009). What Is Sustainable Agriculture? Empirical Evidence of Diverging Views in Switzerland and New Zealand. Ecological Economics, 68, 1872-1882. http://dx.doi.org/10.1016/j.ecolecon.2008.12.016

Altieri, M. (1995). Agroecology: The Scientific Basis of Alternative Agriculture. London: Westview Press and Intermediate Technology.

Barrow, C. J. (1991). Caring for the Earth: A Strategy for Sustainable living. Published by IUCN (World Conservation Union), UNEP (United Nations Environment Programme) and WWF (World Wide Fund for Nature). Retrieved from https://portals.iucn.org/library/efiles/edocs/CFE-003.pdf

Batsell, R. R., \& Lodish, L. M. (1981). A Model and Measurement Methodology for Predicting Individual Consumer Choice. Journal of Marketing Research, 18, 1-12. http://dx.doi.org/10.2307/3151309

Cairol, D., Coudel, E., \& Laplana, R. (2008). Special issue: Multifunctionality of agriculture and rural areas: from trade negotiations to contributing to sustainable development-New challenges for research. International Journal of Agricultural Resources, Governance and Ecology, 7(4/5), 297-436.

Cauwenbergh et al. (2007). SAFE-A Hierarchical Framework for Assessing the Sustainability of Agricultural

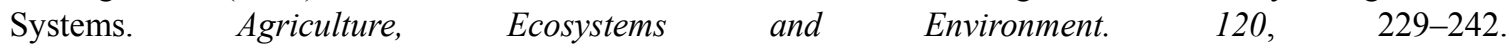
http://dx.doi.org/10.1016/j.agee.2006.09.006

Edwards, C. A. (1987). The Concept of Integrated Systems in Lower Input Sustainable Agriculture. American Journal of Alternative Agriculture, 4, 148-152. http://dx.doi.org/10.1017/S0889189300009255

Fairclough, N. (2004). Analyzing Discourse: Textual Analysis for Social Research. New York: Routledge.

FAO. (1989). Sustainable development and natural resources management. Twenty-Fifth Conference, Food and Agriculture Organization, Rome.

Francis, C. (1990). Sustainable Agriculture: Myths and Realities. Journal of Sustainable Agriculture, 1(1), 97-99. http://dx.doi.org/10.1300/J064v01n01_08

Gafsi, M., Legagneux, B., Nguyen, G., \& Robin, P. (2006). Towards Sustainable Farming Systems: Effectiveness and Deficiency of the French Procedure of Sustainable Agriculture. Agricultural Systems, 90, 226-242. http://dx.doi.org/10.1016/j.agsy.2006.01.002

Hodge, I. (1993). Sustainability: Putting Principles into Practice: An Application to Agricultural Systems. Paper presented to Rural Economy and Society Study Group, Royal Holloway College, December.

Ikerd, J. (1993). Two Related but Distinctly Different Concepts: Organic Farming and Sustainable Agriculture. Small Farm Today, 10(1), 30-31.

Ikerd, J. (2006). Economic analysis and multiple impact valuation strategies. In C. Francis, R. Poincelot, \& G. Bird (Eds.), Developing and Extending Sustainable Agriculture: A New Social Contract (pp. 109-140). Binghamton, NY: Haworth Food and Agricultural Products Press.

Lampkin, N., \& Measures, M. (1995). 1995/96 Organic Farm Management Handbook. University of Wales Elm, Farm Research Centre, Aberystwyth.

Lancaster, K. J. (1966). A New Approach to Consumer Theory. The Journal of Political Economy, 74(2), 132-157. http://dx.doi.org/10.1086/259131

Lewandowski, I., Ha“rdtlein, M., \& Kaltschmitt, M. (1999). Sustainable Crop Production: Definition and 
Methodological Approach for Assessing and Implementing Sustainability. Crop Science, 39, 184-193. http://dx.doi.org/10.2135/cropsci1999.0011183X003900010029x

Lien, G., Hardaker, J. B., \& Flaten, O. (2007). Risk and Economic Sustainability of Crop Farming Systems. Agricultural Systems, 94, 541-552. http://dx.doi.org/10.1016/j.agsy.2007.01.006

Lusk, J. L., \& Norwood, F. B. (2005). Effect of Experimental Design on Choice-Based Conjoint Valuation Estimates. American Journal of Agricultural Economics, 87(3), 771-785. http://dx.doi.org/10.1111/j.1467-8276.2005.00761.

Mac Cormack, H. (1995). Sustainable Agriculture versus Organic Farming. In Bird, Bultena, \& Gardner (Eds.), What is Sustainable Agriculture? Planting the Future: Developing An Agriculture that Sustains Land and Community (pp. 60-61). Iowa State University Press.

Macri, M. C., \& Maria, A. P. (2009). Social Agriculture: A Pattern between Farm Innovation. Social Responsibility and Multifunctionality.

McFadden, D. (1974). Conditional Logit Analysis of Qualitative Choice Behavior. In P. Zarembka (Ed.), Frontiers in Econometrics (pp.105-142). New York: Academic Press.

Paarlberg, R. (2008). Starved for Science. Cambridge, MA: Harvard University Press.

Pretty, J. (1995). Regenerating Agriculture. Policies and Practice for Sustainability and Self-Reliance. London: Earthscan.

Reijntjes, C., Bertus, H., \& Water-Bayer, A. (1992). Farming the Future: an Introduction to Low External Input and Sustainable Agriculture. London: Macmillan.

Rigby, D., \& Caceres, D. (2001). Organic Farming and the Sustainability of Agricultural Systems. Agricultural Systems, 68, 21-40. http://dx.doi.org/10.1016/S0308-521X(00)00060-3

Scofield, A. (1986). Organic Farming: the Origin of the Name. Biological Agriculture and Horticulture, 4, 1-5. http://dx.doi.org/10.1080/01448765.1986.9754481

Siegrist, M. (2003). Perception of Gene Technology, and Food Risks: Results of a Survey in Switzerland. Journal of Risk Research, 6(1), 45-60. http://dx.doi.org/10.1080/1366987032000047798

Sydorovych, O., \& Wossink, A. (2008). The Meaning of Agricultural Sustainability: Evidence from a Conjoint Choice Survey. Agricultural Systems, 98, 10-20. http://dx.doi.org/10.1016/j.agsy.2008.03.001

USDA. (2000). Glickman Announces New Proposal for National Organic Standards. USDA News Release.

Van Calker, K. J., Berentsen, P. B. M., Giesen, G. W. J., \& Huirne, R. B. M. (2005). Identifying and Ranking Attributes that Determine Sustainability in Dutch Dairy Farming. Agriculture and Human Values, 22, 53-63. http://dx.doi.org/10.1007/s10460-004-7230-3

Van Cauwenbergh et al. (2007). SAFE-A Hierarchical Framework for Assessing the Sustainability of Agricultural Systems. Agriculture, Ecosystems and Environment, 120(2-4), 229-242. http://dx.doi.org/10.1016/j.agee.2006.09.006

Whitby, M., \& Adger, W. N. (1996). Natural and Reproductive Capital and the Sustainability of Land Use in the UK. Journal of Agricultural Economics, 47(1), 50-56. http://dx.doi.org/10.1111/j.1477-9552.1996.tb00671.x

York, Jr. E. T. (1991). Agricultural Sustainability and Its Implications to the Horticulture Profession and the Ability to Meet Global Food Needs. Hort Science, 26(10), 1252-1256.

\section{Copyrights}

Copyright for this article is retained by the author(s), with first publication rights granted to the journal.

This is an open-access article distributed under the terms and conditions of the Creative Commons Attribution license (http://creativecommons.org/licenses/by/3.0/). 